Reseña

\section{Alice Teichova (ed.). Central Europe in the Twentieth Century: An Economic History Perspective. New York (USA), Routledge Revivals, 2018, 191 pp. ISBN: 978-1138612570.}

The series Routledge Revivals aims at relaunching academic books that have been influential in the last 120 years.

Alice Teichova is the editor of this 1997 book of essays dealing with the sharp transformations that Central European countries suffered after the fall of the Berlin wall in 1989. The book is mainly a compendium of case studies of transition to market economies for individual countries.

The countries studied in the book are Czechoslovakia, Poland, Yugoslavia, Romania, East Germany, and Austria. The variables studied are macroeconomic indicators such as GDP, prices, and industrial production. The temporal space is the twentieth century, including pre- and post- Second World War. We can find material referring to the interwar period as well as the cold war. However, remember that the focus of the book is a historical perspective viewed from the transition to market economies period.

The editor starts with an introduction that is underlying the importance of history for understanding current events. However, she expresses her concern regarding economists who do not value enough the contribution of historical methodologies. I agree that historical methodologies have been long neglected amongst economists. Yet I disagree with the fact that this continues to be true. Luckily enough for economic history, there has been a raising interest in history amongst economists, and, in my opinion, the 1997 statement is no longer true. Partly, therefore reviving this book now is more interesting than ever. Then she offers an overview of the developments of Eastern Europe in the interwar and the post-Second World War periods, in the form of a preamble to the next chapters, which are country specific case studies.

The first one of the historical case studies is written by Václav Průcha in chapter three, and features Czechoslovakia since its creation in 1918 until it disappeared in 1993. After the separation from Austro-Hungary, Czechoslovakia looked like a good prospect for economic stability compared to the countries surrounding it, who were overwhelmed with hyperinflation. There was a land reform, new markets were sought, and social protection and civil rights emerged. Nevertheless, the old industrial structure dragged the economy to a dreadful decade of the 1930s. A drastic change arrived with the Second World War. The industry was militarised. The socialist orientation of the new government widely nationalised and the country followed a planned economy for the decades to come. The strong restructuring of industry proved not efficient in the long run. Still, when the block finally fell, Czechoslovakia was in a better position than most countries thanks to a good level of education, self-sufficiency of foodstuffs, and a low level of foreign debt.
Chapter four is written by Henryk Szlajfer and it deals with the communist experiment in Poland. He hypothesises that the communist world rejected the market economy but at the same time tried to imitate it. According to Szlajer, this seemed to be the case, at least for Poland. In order to describe this phenomenon, he uses the terms economic nationalism and mimetic industrialisation. The latter refers to meant copying Western development patterns as well as maintaining a certain degree of private property and enterprise. As a result, Poland experimented a relatively mild type of communism, much less autarkic than the Stalinist model. Szlajer borrows the term holistic nationalism from Wilhelm Roepke to describe the "total" economic nationalism taking place after the Second World War, as opposed to particular nationalism englobing targeted industries only.

The rise and fall of Yugoslavia are reviewed by Franjo Štiblar in chapter five. The case study starts with a brief history of the first settlers since the sixth century, and the further movement of the different ethnicities. According to Štiblar, the problem with Yugoslavia was the amalgamation of different nationalities in one single country from the beginning. Once the national sentiments re-emerged the split was inevitable. Additionally, apart from the elongated history of Yugoslavia, the chapter includes a remarkable compendium of socioeconomic statistics.

Daniel Daianu is the responsible person for describing the Romanian transformation (chapter six). This is the country with less economic reforms withing the communist bloc. The Stalinist style centralisation remained and made the country stay in isolationism and inadequate industrial policies. This stubbornness led Romania to stay the poorest of them all. Daianu surveys various theoretical explanations that would have made the transition to a market economy more difficult. These include equilibrium economics within a neoclassical economics framework, a sociological approach, an evolutionary approach, hysteresis, and a crisis of moral values amongst other arguments.

The transition after the collapse of East Germany is described by Jörg Roesler in chapter seven. This chapter is the briefest in chronology since it only covers the transition period from 1989 onwards, but at the same time is the deepest in economic policy analysis. East Germany departed from the best productivity situation of all transition economies and it was catching up quickly with the West. So, investors were supposed to be attracted to the New Länder. However, this was not the case as much as expected, and the process of unification between the two Germanies is far from complete.

Chapter eight deals with the reconstruction of Austria after the Second World War. This is the last one of the country case studies in the book, and it has been written by Fritz Weber. The chapter mainly deals with the process of economic reconstruc- 
tion and focuses on the Marshall Aid and the role of the USA help in general. The author argues that Nazi destruction of capital assets had been previously exaggerated. Weber underlines that internal trade wars between the different occupation zones within Austria was hindering fastest recovery.

The book ends with a transversal chapter on property rights and capital markets written by Michael Kaser. He offers an overall view on the East-West relationships right in the middle of the transformation. Eastern Europe had broadly speaking been a net debtor throughout the twentieth century. Privatisation was a way to reduce public debt, but there were social choices to be made, involving potential unemployment and widening the gap between rich and poor. Kaser thinks that there is a space for international organisations, but the bulk of investments should come from the restoration of property rights by itself.

The book allows us reviving the splendour of economic planning as well as the challenge of transition. The authors take a differentiated approach for each case study. Still, there are numerous parallelisms amongst the countries studied in this book: Most of them where artificially created out of the peace treaties of the First World Word in 1918 and ceased existence with the definite fall of the iron curtain. The communist economic order was shared simultaneously for a long period of time. All of them launched reforms to move towards mixed systems around the 1960s. Unfortunately, evidence of decadence was blatantly patent in the 1980s, and, finally, the definite collapse occurred around 1990. The study of every country's particularities brings us to a new challenge in every chapter.

Marta Felis-Rota

Universidad Autónoma de Madrid

https://doi.org/10.33231/j.ihe.2020.12.002 